\title{
Gambaran Kecenderungan Orthorexia Nervosa pada Mahasiswa Program Studi Kedokteran FK-KMK UGM
}

\section{Prevalance of Orthorexia Nervosa Tendency among Medical Students at FK-KMK UGM}

\author{
Mutiara Anisha Zahra ${ }^{1}$, Irwan Supriyanto ${ }^{2}$, Sri Warsini ${ }^{3}$ \\ ${ }^{1}$ Program Studi Keperawatan Fakultas Kedokteran, Kesehatan Masyarakat, dan \\ Keperawatan, Universitas Gadjah Mada, Yogyakarta \\ ${ }^{2}$ Departemen Kedokteran Jiwa Fakultas Kedokteran, Kesehatan Masyarakat, dan \\ Keperawatan, Universitas Gadjah Mada, Yogyakarta \\ ${ }^{3}$ Departemen Keperawatan Jiwa dan Komunitas, Fakultas Kedokteran, Kesehatan \\ Masyarakat, dan Keperawatan, Universitas Gadjah Mada, Yogyakarta
}

\begin{abstract}
Background: Orthorexia nervosa $(\mathrm{ON})$ is a new psychological disorder that still needs further research. People living with ON have unsafe obsession with eating healthy food. Research related to ON among graduate students in Indonesia, especially medical students, has not been done.

Research Objectives: This study aims to determine the proportion of orthorexia nervosa (ON) tendency and to investigate certain characteristics that might influence $\mathrm{ON}$ tendency among medical students at FK-KMK UGM.

Methodology: This research was a descriptive study with a cross-sectional design. Data collection took place in October-November 2019. Respondents involved were 97 students. The instrument used was ORTO-15. The results were analysed with Chi-Square Test and Fisher Test.

Results: The proportion of ON tendency among respondents was $44.3 \%$ (cut-off point 40 ) and there were significant relationship between $\mathrm{ON}$ tendency with the habit of respondents to access health related articles in web pages and social media.

Conclusion: The ON tendency among medical students in FK-KMK UGM is relatively high with a prevalence percentage of $44.3 \%$. Prevention efforts need to be made so that this trend does not develop into an actual health problem.
\end{abstract}

Keywords: eating disorders; medical student; ORTO-15, orthorexia nervosa

\begin{abstract}
ABSTRAK
Latar Belakang: Orthorexia nervosa (ON) merupakan gangguan psikologis baru yang masih perlu banyak diteliti dengan ciri-ciri penderita memiliki obsesi berlebih terhadap pola makan yang dianggap sehat. Hingga saat ini penelitian terkait ON pada mahasiswa di Indonesia, khususnya mahasiswa kedokteran belum dilakukan.

Tujuan Penelitian: Penelitian ini bertujuan untuk mengetahui proporsi kecenderungan orthorexia nervosa (ON) dan karakteristik responden yang memengaruhi kecenderungan ON pada mahasiswa Prodi Kedokteran FK-KMK UGM.

Metodologi: Penelitian ini adalah penelitian deskriptif dengan desain cross-sectional. Pengambilan data berlangsung pada bulan Oktober-November tahun 2019. Responden yang terlibat sebanyak 97 mahasiswa. Instrumen yang digunakan adalah ORTO-15. Hasil analisa dilakukan dengan Chi-square dan Fisher test.

Hasil: Proporsi kecenderungan ON pada responden adalah 44,3\% (cut-off point 40). Ditemukan hubungan signifikan antara kecenderungan $\mathrm{ON}$ dengan kegemaran responden untuk mengakses laman berkaitan dengan kesehatan di sosial media $(p<0,05)$.

Kesimpulan: Kecenderungan ON pada mahasiswa kedokteran FK-KMK UGM tergolong tinggi. Perlu dilakukan upaya pencegahan agar kecenderungan ini tidak berkembang menjadi masalah kesehatan yang aktual.
\end{abstract}

Kata Kunci: gangguan makan; mahasiswa kedokteran; ORTO-15, orthorexia nervosa

Gedung Ismangoen, Kompleks FKKMK UGM, Jl.Farmako Sekip Utara, Sendowo, Sinduadi, Mlati, Sleman, Yogyakarta 55281

Email:sri.warsini@ugm.ac.id 


\section{PENDAHULUAN}

Penerapan pola makan sehat merupakan hal yang baik dan memang sangat dianjurkan untuk menghindari berbagai macam penyakit, bahkan hal tersebut disarankan oleh tenaga kesehatan. Namun, penerapan pola makan sehat ini bisa menjadi suatu hal yang patologis, apabila seseorang mulai terobsesi dengan pola makan sehat dan berujung pada terganggunya kehidupan sosial orang tersebut.

Orthorexia nervosa (ON) adalah gangguan psikologis pada penderita yang memiliki obsesi berlebih terhadap suatu pola makan yang dianggap sehat. Orang tersebut menghabiskan banyak waktu hanya untuk merencanakan, membeli, mempersiapkan, dan mengonsumsi makanannya. ${ }^{1}$ Ciri khas Orthorexia nervosa yaitu pengidapnya memiliki pemikiran obsesif, perilaku kompulsif, sikap menghukum diri sendiri, dan menentukan pantangan-pantangan dalam hal memilih makanan. ${ }^{1}$ Ciri lainnya adalah menolak untuk mengonsumsi makanan yang mengandung residu pestisida, makanan genetically modified organism (GMO), makanan dengan lemak tidak sehat, dan makanan yang mengandung terlalu banyak garam atau gula. ${ }^{2}$

Perbedaan antara orthorexia nervosa dan anorexia nervosa adalah seseorang dengan ON tidak memiliki masalah terhadap body image. Berbeda dengan gangguan anorexia nervosa, penderitanya memiliki keinginan yang kuat untuk menurunkan berat badan dan memiliki masalah body image. ${ }^{3}$

Terdapat beberapa faktor yang dapat menyebabkan seseorang berisiko terhadap ON. Beberapa di antaranya adalah seseorang yang berasal dari keluarga dengan tingkat penghasilan tinggi ${ }^{4}$, memiliki latar belakang pendidikan tinggi ${ }^{5}$, memiliki kepribadian narsisme, perfeksionisme dan obsessive-compulsive tendencies ${ }^{6}$, memiliki riwayat gangguan makan ${ }^{7,8,9}$ dan riwayat gangguan psikologis, seperti depresi, anxiety, Obsessive Compulsie Disorder, dan afek negatif. ${ }^{6,10-12}$ Selain itu, individu yang menganut pola makan vegetarian atau vegan ${ }^{10,11,13}$, atau individu yang sedang atau pernah menjalani diet khusus ${ }^{11,13-15}$ juga berisiko mengalami ON.

Prevalensi ON dari penelitian yang dilakukan di beberapa negara menggunakan ORTO15 (sebuah kuesioner berisi 15 item pilihan ganda yang telah diuji untuk mengidentifikasi ON) ${ }^{16}$, didapatkan gambaran kejadian terhadap kecenderungan ON lebih dari 55\% (dengan cut off point 40 ) dan kurang dari $12 \%$ (dengan cut off point 35 ) pada populasi umum di Itali. ${ }^{17}$ Penelitian lain juga dilakukan di Austria ${ }^{11}$, dengan meneliti populasi umum berjumlah 1.029 orang dan didapat hasil hampir $70 \%$ dari sampel terdeteksi memiliki kecenderungan $\mathrm{ON}$.

Obsesi tidak sehat yang dimiliki penderita ON terhadap pola makan sehat dapat berdampak buruk pada psikologis maupun fisiologis penderitanya. Pada penelitian yang dilakukan oleh Saddichha et al $^{18}$ dan Lopes et al ${ }^{19}$, didapatkan hasil bahwa ON dapat berdampak buruk kepada kehidupan sosial penderitanya, misal mereka menarik diri dari 
masyarakat, mengisolasi diri dari keluarga maupun teman terdekat, dan paranoid terhadap makanan yang bukan buatannya sendiri. Dalam beberapa kasus yang telah dilaporkan oleh beberapa pasien terindikasi ON, ternyata mereka perlu dirawat di rumah sakit karena kasus malnutrisi dan BMI di bawah normal. ${ }^{18,19,20}$ Tidak hanya itu, pada kasus yang dilaporkan oleh Park et al. ${ }^{21}$ seorang pasien dengan indikasi ON dirawat dengan diagnosa pancytopenia, metabolic acidosis, pneumothorax, dan subcutaneous emphysema.

Penelitian terhadap prevalensi ON pada populasi khusus berlatar belakang pendidikan kesehatan telah dilakukan sebelumnya yaitu salah satunya pada mahasiswa kedokteran di Turki dengan hasil lebih $42 \%$ dari 878 mahasiswa memiliki indikasi yang mengarah pada karakteristik ON. ${ }^{21}$ Dampak ON pada mahasiswa kedokteran dapat berupa menurunnya performa akademis. Hal tersebut didukung dengan korelasi antara gangguan psikologis dengan performa akademis mahasiswa, yakni mahasiswa yang mengalami gangguan psikologis memiliki tingkat akademik lebih buruk dibanding mahasiswa yang tidak memiliki gangguan psikologis. ${ }^{22,23}$

Sejauh ini, penelitian terkait gambaran ON pada mahasiswa kedokteran di Indonesia atau di Yogyakarta khususnya belum pernah dilakukan. Oleh karena itu, penelitian ini dirasa penting untuk dilakukan.

Tujuan penelitian ini adalah untuk mengetahui gambaran kejadian kecenderungan orthorexia nervosa dan untuk mengetahui karakteristik responden (jenis kelamin, usia, tingkat pendidikan, Indeks Massa Tubuh (IMT), kebiasaan olahraga, penggunaan sosial media, dan pola makan) yang memengaruhi kecenderungan ON pada mahasiswa kedokteran FK-KMK di UGM.

\section{METODE PENELITIAN}

Penelitian ini adalah penelitian deskriptif dengan desain cross-sectional. Penelitian dilakukan pada Oktober-November tahun 2019 di Program Studi S1 Kedokteran FK-KMK UGM. Subjek pada penelitian ini adalah mahasiswa Program Studi S1 Kedokteran FK-KMK UGM angkatan 2016, 2017, dan 2018 yang tercatat aktif pada periode Oktober-November tahun 2019.

Jumlah sampel ditentukan menggunakan proporsional stratified random sampling. Sampel dibagi berdasarkan angkatan (stratified). Jumlah responden per angkatan dihitung secara proporsional. Kemudian responden dipilih menggunakan random sampling. Pada proses pengambilan data, sampel yang diambil sebanyak 101 mahasiswa. Namun, ada 4 responden yang tidak menjawab seluruh soal, maka data yang dianalisis adalah 97 responden.

Instrumen yang digunakan pada penelitian ini adalah ORTO-15 yang berisi 15 item pertanyaan dengan skor tiap pertanyaan adalah 1-4 (selalu, sering, kadang-kadang, tidak pernah). Instrumen ini diadaptasi dari Bratman Orthorexia Test (BOT) yang merupakan 
instrumen diagnosa ON pertama yang dibuat dan telah digunakan sebelumnya pada populasi di Amerika. ${ }^{16}$ Untuk mengidentifikasi kecenderungan ON, cut off point yang ditentukan adalah 40 , dengan hasil skor yang rendah mengindikasikan adanya ON.

Pertanyaan pada ORTO-15 bertujuan untuk menyelidiki aspek emosional, kognitifrasional, dan klinis bagi subjek yang didiagnosa. Pertanyaan nomor 1, 5, 6, 11, 12, 14 untuk menyelidiki area kognitif-rasional, pertanyaan nomor 3, 7, 8, 9, 15 untuk menyelidiki area klinis, dan pertanyaan nomor 2, 4, 10, dan 13 untuk menyelidiki area emosional. Jawaban dari pertanyaan yang mengindikasikan ON diberikan skor "1" dan untuk yang lebih "sehat" diberikan skor "4". Jumlah skor seluruh pertanyaan merupakan skor final dari tes yang dilakukan ${ }^{24}$.

Analisis data yang digunakan adalah analisis univariat dan bivariat. Analisis univariat digunakan untuk menganalisis karakteristik variabel responden yang diteliti, yaitu jenis kelamin, usia, tingkat pendidikan, indeks massa tubuh (IMT), penggunaan sosial media, kebiasaan berolahraga dan pola makan, serta gambaran kejadian kecenderungan ON pada mahasiswa prodi kedokteran. Analisis bivariat dilakukan untuk mengetahui karakteristik responden yang memengaruhi kecenderungan $\mathrm{ON}$ dan dilakukan dengan Uji Chi-square dan Fischer Test.

Etika penelitian telah didapatkan dari Komisi Etik Fakultas Kedokteran, Kesehatan Masyarakat dan Keperawatan di Universitas Gadjah Mada dengan No: KE/FK/0653/EC/2019. Informed consent diberikan kepada responden sebelum pengambilan data dilakukan, hal ini untuk menjadi tanda kesediaan dan persetujuan responden dan peneliti.

\section{HASIL}

Jumlah responden yang dianalisis sebanyak 97 mahasiswa. Terdapat dua jenis karakteristik responden pada penelitian ini, yaitu karakteristik umum responden dan karakteristik yang memengaruhi kecenderungan ON. Karakteristik responden ditampilkan pada Tabel 1 dan 2.

Tabel 1. Karakteristik umum pada mahasiswa Prodi Kedokteran FK-KMK UGM bulan Oktober-November tahun $2019(n=97)$

\begin{tabular}{|c|c|c|c|c|}
\hline Karakteristik & $\mathbf{f}$ & $\%$ & Mean士SD & Min-Max \\
\hline \multicolumn{5}{|l|}{ Angkatan } \\
\hline 2016 & 35 & 36,0 & & \\
\hline 2017 & 31 & 32,0 & & \\
\hline 2018 & 31 & 32,0 & & \\
\hline \multicolumn{5}{|l|}{ Jenis kelamin } \\
\hline Perempuan & 54 & 55,7 & & \\
\hline Laki-laki & 43 & 44,3 & & \\
\hline \multicolumn{5}{|l|}{ Usia (tahun) } \\
\hline Remaja Akhir (18 -19) & 36 & 37,1 & & \\
\hline Dewasa Awal (20 - 22) & 61 & 62,9 & $20,01 \pm 1,08$ & $18-22$ \\
\hline Berat badan (kg) & & & $61,43 \pm 14,83$ & $36-110$ \\
\hline Tinggi badan (m) & & & $1,63 \pm 0,08$ & $1,40-1,85$ \\
\hline
\end{tabular}

Dari Tabel 1 diketahui bahwa sebagian besar responden berjenis kelamin perempuan. Mahasiswa terdistribusi secara proporsional berdasarkan angkatan. Rentang usia mahasiswa 
pada penelitian ini adalah 18-22 tahun. Mean berat badan mahasiswa adalah $61,43 \pm 14,83 \mathrm{~kg}$

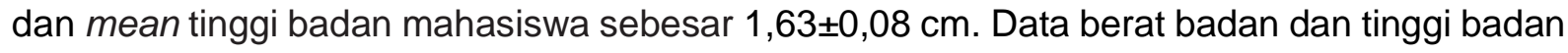
mahasiswa merupakan data self-report dan tidak dilakukan pengukuran berat badan dan tinggi badan yang sebenarnya.

Tabel 2. Karakteristik yang mempengaruhi kecenderungan ON pada mahasiswa Prodi Kedokteran FK-KMK UGM bulan Oktober-November tahun 2019 ( $n=97)$

\begin{tabular}{|c|c|c|}
\hline $\begin{array}{l}\text { Karakteristik } \\
\end{array}$ & $f$ & $\%$ \\
\hline \multicolumn{3}{|l|}{ Indeks massa tubuh (IMT) } \\
\hline Gizi kurang & 15 & 15,5 \\
\hline Gizi baik & 60 & 61,8 \\
\hline Gizi lebih & 22 & 22,7 \\
\hline \multicolumn{3}{|l|}{ Alergi } \\
\hline $\mathrm{Ya}$ & 15 & 15,5 \\
\hline Tidak & 82 & 84,5 \\
\hline \multicolumn{3}{|l|}{ Diet Khusus } \\
\hline $\mathrm{Ya}$ & 1 & 1,0 \\
\hline Tidak & 96 & 99,0 \\
\hline \multicolumn{3}{|l|}{ Frekuensi Makan } \\
\hline Normal & 57 & 58,8 \\
\hline Tidak normal & 40 & 41,2 \\
\hline \multicolumn{3}{|l|}{ Tingkat Aktivitas Fisik } \\
\hline Tidak aktif \& sedikit aktif & 76 & 78,4 \\
\hline Aktif \& sangat aktif & 21 & 21,6 \\
\hline \multicolumn{3}{|l|}{ Jenis Olahraga $(n=84)$} \\
\hline Jogging, lari, jalan kaki, renang (grup 1) & 50 & 59,5 \\
\hline Senam dan zumba (grup 2) & 5 & 6,0 \\
\hline Angkat beban, push-up, sit up, gym (grup 3) & 19 & 22,6 \\
\hline Futsal, basket, bulu tangkis (grup 4) & 10 & 11,9 \\
\hline \multicolumn{3}{|l|}{ Frekuensi Olahraga } \\
\hline Tidak tentu & 39 & 40,2 \\
\hline 1x/bulan & 16 & 16,5 \\
\hline $1 \mathrm{x} /$ minggu & 28 & 28,9 \\
\hline 1x/hari & 14 & 14,4 \\
\hline \multicolumn{3}{|l|}{ Lama Waktu Olahraga } \\
\hline$<30$ menit/hari & 35 & 36,1 \\
\hline 30 menit/hari & 30 & 30,9 \\
\hline 60 menit/minggu & 15 & 15,5 \\
\hline 60 menit/bulan & 17 & 17,5 \\
\hline \multicolumn{3}{|l|}{ Mengikuti Klub Olahraga } \\
\hline $\mathrm{Ya}$ & 18 & 18,6 \\
\hline Tidak & 79 & 81,4 \\
\hline \multicolumn{3}{|l|}{ Jumlah Kepemilikan Akun Sosial Media } \\
\hline 1 akun & 22 & 22,7 \\
\hline 2 akun & 26 & 26,8 \\
\hline 3 akun & 33 & 34,0 \\
\hline$>3$ akun & 16 & 16,5 \\
\hline \multicolumn{3}{|l|}{ Akun Sosial Media* } \\
\hline Facebook & 58 & 59,8 \\
\hline Twitter & 46 & 47,4 \\
\hline Instagram & 87 & 89,7 \\
\hline LINE & 30 & 30,9 \\
\hline WhatsApp & 17 & 17,5 \\
\hline \multicolumn{3}{|l|}{ Durasi Menggunakan Sosial Media } \\
\hline$<1$ jam-2jam/hari & 33 & 34,0 \\
\hline$>2$ jam/hari & 64 & 66,0 \\
\hline \multicolumn{3}{|l|}{ Laman yang Digemari* } \\
\hline Makanan & 47 & 48,5 \\
\hline Kesehatan & 36 & 37,1 \\
\hline Hiburan & 22 & 22,7 \\
\hline Public figure & 34 & 35,1 \\
\hline Olahraga & 12 & 12,4 \\
\hline
\end{tabular}

* boleh memilih lebih dari 1 macam 
Pada Tabel 2, terdapat distribusi frekuensi karakteristik yang memengaruhi kecenderungan ON. Berdasarkan hasil analisis, 61,9\% mahasiswa memiliki gizi baik atau normal dengan IMT 18,5-24,9. Hanya 15 mahasiswa yang melaporkan memiliki alergi dan kebanyakan alergi yang diderita adalah alergi pada makanan, terutama makanan laut (udang, cumi, dan kepiting). Dari 97 mahasiswa yang diteliti, hanya 1 mahasiswa yang melaporkan memiliki diet khusus.

Sebanyak 57 mahasiswa pada penelitian ini dikategorikan memiliki pola frekuensi makan yang normal (dikategorikan frekuensi makan normal jika mahasiswa memiliki frekuensi makan $3 x /$ hari dan kategori frekuensi makan tidak normal jika mahasiwa hanya makan $<3 x$ atau $>3 x$ /hari). Sebanyak $78,4 \%$ mahasiswa pada penelitian ini tidak memiliki gaya hidup yang aktif atau hanya sedikit aktif.

Jenis olahraga yang paling sering dilakukan oleh mahasiswa adalah jenis olahraga cardio seperti jogging, jalan kaki, dan berenang. Sebanyak 40,2\% mahasiswa tidak memiliki jadwal waktu olahraga yang teratur dan hanya $14,4 \%$ mahasiswa yang rutin melakukan olahraga setiap hari. Lama waktu olahraga yang dilakukan oleh mahasiswa kurang lebih 30 menit dalam setiap sesi olahraga. Mayoritas mahasiswa tidak mengikuti klub olahraga tertentu dan hanya 18 orang yang memiliki membership klub olahraga, kebanyakan jenis klub olahraga yang diikuti oleh mahasiswa adalah gym membership.

Penggunaan sosial media mahasiswa terbagi rata dengan seluruh mahasiswa memiliki setidaknya 1 akun sosial media. Sosial media yang paling banyak digunakan oleh mahasiswa adalah Instagram. Laman yang paling sering diakses oleh mahasiswa adalah laman bertema makanan (48,5\%), disusul dengan laman yang berkaitan dengan kesehatan $(37,1 \%)$, dan laman yang berisikan public figure (35,1\%). Sebanyak $66 \%$ mahasiswa mengakses sosial media selama lebih dari 2 jam dalam kurun waktu sehari.

\begin{tabular}{|c|c|c|c|c|c|}
\hline \multirow[t]{2}{*}{ Variabel } & \multicolumn{2}{|c|}{$\begin{array}{c}\text { ORTO-15 } \\
\text { (cut-off point 40) }\end{array}$} & \multicolumn{2}{|c|}{$\begin{array}{c}\text { ORTO-15 } \\
\text { (cut-off point 35) }\end{array}$} & \multirow[t]{2}{*}{ Mean $\pm S D$} \\
\hline & $f$ & $\%$ & $f$ & $\%$ & \\
\hline \multicolumn{6}{|c|}{ Kecenderungan ON } \\
\hline $\mathrm{Ya}$ & 43 & 44,3 & 6 & 6,2 & $40,06 \pm 2,89$ \\
\hline Tidak & 54 & 55,7 & 91 & 93,8 & \\
\hline
\end{tabular}

Pada Tabel 3 ditampilkan gambaran kecenderungan ON pada responden. Proporsi kecenderungan ON pada 97 mahasiswa dianalisis menggunakan 2 jenis cut-off point, yaitu 40 dan 35 . Hasil proporsi menggunakan cut-off point 40 adalah $44,3 \%$, sedangkan hasil proporsi menggunakan cut-off point 35 adalah 6,2\%. Nilai cut-off point sebesar 40 ditentukan berdasarkan referensi pencipta ORTO-15 yaitu Donini ${ }^{25}$ pada tahun 2005. Sementara nilai cutoff point 35 adalah berdasarkan rekomendasi beberapa penelitian sebelumnya yaitu Hyrnik et 
al. ${ }^{4}$ dan Reynolds. ${ }^{14}$ Pada penelitian ini cut-off point yang digunakan sebagai acuan adalah cut-off point 40 mengingat ORTO-15 dibuat oleh Donini.

Tabel 4. Analisis hubungan faktor ON dengan kecenderungan ON ( $n=97)$

\begin{tabular}{|c|c|c|c|}
\hline \multirow{2}{*}{ Karakteristik } & \multicolumn{2}{|c|}{ Kecenderungan ON } & \multirow{2}{*}{ p-value } \\
\hline & Ya & Tidak & \\
\hline \multicolumn{4}{|l|}{ Jenis kelamin } \\
\hline Perempuan & 24 & 30 & \multirow{2}{*}{$0,980^{\mathrm{a}}$} \\
\hline Laki-laki & 19 & 24 & \\
\hline \multicolumn{4}{|l|}{ Usia } \\
\hline Remaja akhir & 18 & 18 & \multirow{2}{*}{$0,388^{a}$} \\
\hline Dewasa awal & 25 & 36 & \\
\hline \multicolumn{4}{|l|}{ Indeks Massa Tubuh (IMT) } \\
\hline Gizi kurang & 9 & 6 & \multirow{3}{*}{$0,413^{a}$} \\
\hline Gizi baik & 25 & 35 & \\
\hline Gizi lebih & 9 & 13 & \\
\hline \multicolumn{4}{|l|}{ Alergi } \\
\hline $\mathrm{Ya}$ & 7 & 8 & \multirow[b]{2}{*}{$0,843^{a}$} \\
\hline Tidak & 36 & 46 & \\
\hline \multicolumn{4}{|l|}{ Diet khusus } \\
\hline $\mathrm{Ya}$ & 1 & 0 & \multirow[b]{2}{*}{$0,443^{b}$} \\
\hline Tidak & 42 & 54 & \\
\hline \multicolumn{4}{|l|}{ Frekuensi makan } \\
\hline Normal (3x sehari) & 26 & 31 & \multirow[b]{2}{*}{$0,761^{a}$} \\
\hline Tidak normal $(<3 x$ atau $>3 x$ sehari) & 17 & 23 & \\
\hline \multicolumn{4}{|l|}{ Tingkat aktivitas fisik } \\
\hline Tidak aktif \& sedikit aktif & 33 & 43 & \multirow[b]{2}{*}{$0,732^{\mathrm{a}}$} \\
\hline Aktif \& sangat aktif & 10 & 11 & \\
\hline Frekuensi olahraga & & & \\
\hline Tidak tentu atau $1 \mathrm{x} / \mathrm{bulan}$ & 23 & 32 & \\
\hline $1 \mathrm{x} /$ hari atau $1 \mathrm{x} / \mathrm{minggu}$ & 20 & 22 & $0,569^{a}$ \\
\hline Lama waktu olahraga & & & \\
\hline$\leq 60 \mathrm{menit} / \mathrm{minggu}$ & 12 & 20 & \\
\hline$\leq 30$ atau $\geq 30$ menit/hari & 31 & 34 & $0,342^{\mathrm{a}}$ \\
\hline Jumlah kepemilikan akun sosial me & & & \\
\hline 1-2 Akun & 20 & 28 & \\
\hline$>2$ Akun & 23 & 26 & $0,601^{\mathrm{a}}$ \\
\hline Durasi menggunakan sosial media & & & \\
\hline <1jam-2jam/hari & 17 & 16 & \\
\hline >2jam/hari & 26 & 38 & $0,306^{a}$ \\
\hline Akun sosial media: facebook & & & \\
\hline $\mathrm{Ya}$ & 22 & 36 & 1020 \\
\hline Tidak & 21 & 18 & $0,122^{\mathrm{a}}$ \\
\hline Akun sosial media: twitter & & & \\
\hline $\mathrm{Ya}$ & 20 & 26 & \\
\hline Tidak & 23 & 28 & $0,873^{a}$ \\
\hline Akun sosial media: instagram & & & \\
\hline $\mathrm{Ya}$ & 39 & 48 & \\
\hline Tidak & 4 & 6 & $0,771^{\mathrm{a}}$ \\
\hline Akses laman makanan & & & \\
\hline Ya & 19 & 28 & $0,453^{a}$ \\
\hline Tidak & 24 & 26 & \\
\hline Akses laman kesehatan & & & \\
\hline $\mathrm{Ya}$ & 21 & 15 & $0,033^{a *}$ \\
\hline Tidak & 22 & 39 & \\
\hline Akses laman hiburan & & & \\
\hline $\mathrm{Ya}$ & 9 & 13 & $0,713^{a}$ \\
\hline Tidak & 34 & 41 & \\
\hline Akses laman public figure & & & \\
\hline Ya & 15 & 19 & $0,975^{a}$ \\
\hline Tidak & 28 & 35 & \\
\hline Akses laman olahraga & & & \\
\hline Ya & 5 & 7 & \\
\hline Tidak & 38 & 47 & $0,843^{a}$ \\
\hline
\end{tabular}


Tabel 4 berisikan analisis hubungan antara karakteristik responden dengan kecenderungan ON. Berdasarkan data hasil analisis di atas, ditemukan adanya hubungan signifikan antara kecenderungan $\mathrm{ON}$ dengan kegemaran mahasiswa untuk mengakses laman yang berkaitan dengan kesehatan. Selain karakteristik responden satu ini, karakteristik lain tidak menunjukkan adanya hubungan signifikan dengan kecenderungan terhadap ON.

\section{PEMBAHASAN}

Berdasarkan analisis penelitian ini, proporsi kecenderungan ON pada mahasiswa kedokteran menggunakan ORTO-15 (cut-off point 40) adalah 43\%. Prevalensi tersebut merupakan angka yang cukup tinggi. Hal ini selaras dengan penelitian sebelumnya yang juga dilakukan pada mahasiswa kedokteran di Lebanon dengan prevalensi 74,5\% dari 627 mahasiswa kedokteran ${ }^{26}$ dan di Turki dengan prevalensi 43,6\% dari 878 mahasiswa kedokteran memiliki kecenderungan $\mathrm{ON} .^{22}$

Proporsi kecenderungan ON pada mahasiswa kedokteran cukup tinggi di antaranya disebabkan oleh berbagai alasan. Kuliah di jurusan yang mempelajari kesehatan, tidak hanya memberikan pengetahuan terkait nutrisi dan kesehatan, tetapi juga meningkatkan kesadaran seseorang yang terpapar informasi tersebut, sehingga menjadi lebih paham mengenai pentingnya hubungan antara nutrisi sehat dan seimbang, dengan kesehatan seseorang. ${ }^{27}$ Selain itu, menekuni jurusan yang berkaitan dengan kesehatan dapat memotivasi dan mendorong seseorang untuk mencari tahu mengenai informasi mengenai nutrisi dan kesehatan di luar program studi yang mereka tekuni, dengan salah satu tujuan dari motivasi tersebut untuk mengubah perilaku makan. ${ }^{28}$

Pada penelitian ini didapatkan bahwa meskipun tidak ada hubungan yang signifikan antara usia dan kecenderungan ON, tetapi ditemukan bahwa kelompok mahasiswa usia dewasa muda lebih banyak yang memiliki kecenderungan terhadap ON dibanding kelompok usia remaja akhir. Sebanyak 62,9\% mahasiswa termasuk kategori dewasa awal yaitu berusia 20-22 tahun. Hasil analisis antara hubungan usia dan kecenderungan ON pada penelitian ini memiliki kesamaan dengan beberapa penelitian lainnya yang juga tidak menemukan hubungan yang signifikan antara usia dan kecenderungan ON, yaitu penelitian Bundros et al. ${ }^{29}$, Depa et al. ${ }^{30}$, Herranz Valera et al. ${ }^{31}$, Reynolds ${ }^{14}$, Turner \& Lefevre. ${ }^{32}$

Kebanyakan dari responden berpendapat bahwa mereka tidak berpikir terlalu keras untuk menentukan pilihan makanan yang akan mereka makan. Meski begitu, mereka berpendapat bahwa pengetahuan yang mereka dapatkan dari proses belajar di perkuliahan cukup memengaruhi persepsi mereka terhadap healthy eating. Banyak dari mereka yang menerapkan pengetahuan tersebut pada kehidupan sehari-hari dan secara sadar berusaha memilih makanan yang lebih bernutrisi. Namun, kebiasaan tersebut masih dalam standar yang mereka anggap normal dan tidak mengganggu kehidupan akademis atau sosial yang mereka 
miliki. Hanya 7 dari 97 mahasiswa yang melaporkan bahwa proses belajarnya terganggu karena pola makan yang mereka miliki. Alasan yang disampaikan bervariasi, ada yang berhubungan dengan kriteria ON dan ada yang tidak, seperti contohnya mengantuk bila terlalu banyak makan atau ketika belum makan, sehingga menjadi tidak fokus dalam belajar, dan menentukan pilihan makan terlalu lama, sehingga menunda atau tidak fokus dalam belajar. Dari 7 mahasiswa tersebut, hanya 2 orang yang alasannya sesuai dengan kriteria ON yaitu terlalu lama menentukan pilihan makan, sehingga menyebabkan kurang fokus dalam memperhatikan proses perkuliahan atau jadi menunda belajar mandiri. Namun, jika hanya dengan infromasi tersebut, tidaklah cukup untuk mengetahui secara pasti, bahwa kecenderungan terhadap $\mathrm{ON}$ yang menjadi penyebab terganggunya proses akademik mahasiswa.

Selain itu 2 mahasiswa melaporkan bahwa kebiasaan makan yang dimiliki, yaitu kebiasaan menolak makan di tempat yang kurang bersih menjadi salah satu faktor mereka menolak untuk melakukan social-eating bersama teman atau koleganya. Hal ini menjadi indikasi bahwa mayoritas mahasiswa tidak merasa kehidupan sosialnya terganggu dengan kebiasaan makan yang mereka miliki. Hal ini diduga karena pengaruh kuat budaya yang ada di Indonesia, yang kaya dengan variasi makanan dan kebanyakan orang Indonesia tidak terlalu ambil pusing mengenai pemilihan makanan sehari-hari.

Penelitian ini menunjukkan adanya hubungan yang signifikan antara karakteristik mahasiswa dengan kecenderungan $\mathrm{ON}$, yaitu kebiasaan mahasiswa dalam mengakses laman kesehatan pada sosial media. Dengan mengakses laman kesehatan, maka informasi mahasiswa mengenai penyakit dan atau kesehatan menjadi bertambah, sehingga kepercayaan, persepsi, dan kesadaran mahasiswa mengenai kesehatan juga terpengaruh. Bagci Bosi et al. ${ }^{33}$ berpendapat bahwa seseorang yang teredukasi lebih mengenai kesehatan, biasanya akan lebih tertarik atau berkeinginan untuk menjadi sehat dan mengonsumsi nutrisi yang sesuai dan lebih tertarik pada healthy eating. ${ }^{33}$ Kesadaran terhadap kesehatan sangat berpengaruh dengan perilaku kesehatan seseorang, sehingga dapat menjadi salah satu penyebab kecenderungan $\mathrm{ON}$.

Penelitian yang menghubungkan kecenderungan ON dengan kebiasaan mengakses laman tertentu pada sosial media belum pernah dilakukan sebelumnya, maka ini menjadi penelitian pertama yang menunjukkan adanya hubungan antara kedua hal tersebut. Berdasarkan ulasan sistematik yang dilakukan oleh Mccomb \& Mills ${ }^{34}$, pengaruh sosial media dengan kecenderungan $\mathrm{ON}$ masih diragukan karena sejauh ini hanya ada satu penelitian ${ }^{30}$ yang menghubungkan antara kecenderungan $\mathrm{ON}$ dan penggunaan sosial media. Hasil dari penelitian Turner \& Levere ${ }^{32}$ menunjukkan bahwa $49 \%$ responden penelitian mereka memiliki kecenderungan $\mathrm{ON}$. Laman yang berhubungan dengan makanan menjadi hal yang paling banyak terdapat di beranda pengguna Instagram pada penelitian Turner \& Levere. ${ }^{32}$ Pada 
penelitian ini akses terhadap sosial media, seperti Instagram, Twitter, Facebook, WhatsApp dan Line belum dapat membuktikan pengaruh sosial media dengan kecenderungan ON dikarenakan hasil yang didapatkan tidaklah signifikan. Selain kepemilikan akun sosial media, durasi akses sosial media dalam sehari yang dilakukan mahasiswa juga secara statistik tidak signifikan dengan kecenderungan ON pada mahasiswa kedokteran.

Penelitian mengenai hubungan jenis kelamin dan kecenderungan $\mathrm{ON}$ masih belum dapat disimpulkan secara pasti. Pada penelitian ini, mahasiswa perempuan memiliki kecenderungan lebih tinggi terhadap ON dibanding mahasiswa pria. Meski begitu, tidak ada hubungan yang signifikan antara jenis kelamin dan kecenderungan ON pada penelitian ini. Hal ini didukung dengan penelitian sebelumnya yang juga menemukan hasil bahwa jenis kelamin tidak memiliki hubungan dengan kecenderungan ON. 6,10,14,30,35,36

Mayoritas responden yang diteliti, yaitu sebanyak $78,6 \%$ mahasiswa tidak memiliki gaya hidup yang aktif. Jenis olahraga yang biasa dilakukan mahasiswa adalah olahraga jenis kardio, contohnya jogging, lari, jalan kaki, renang, dan olahraga sejenisnya. Mayoritas mahasiswa tidak memiliki jadwal olahraga tertentu. Hasil analisis antara hubungan aktivitas fisik dan kebiasaan olahraga dengan kecenderungan ON pada penelitian ini tidak signifikan dan hasil tersebut memiliki kesamaan dengan beberapa penelitian lainnya yang juga tidak menemukan hubungan yang signifikan antara aktivitas fisik dan kebiasaan olahraga dengan kecenderungan ON, yaitu penelitian Brytek-Matera et al. ${ }^{9}$ dan Dunn et al. ${ }^{35}$

Meskipun pada penelitian ini tidak ditemukan hubungan signifikan antara IMT dan kecenderungan $\mathrm{ON}$, namun didapat hasil bahwa mahasiswa dengan kategori gizi baik atau normal memiliki kecenderungan lebih besar mengalami ON dibanding mahasiswa yang termasuk kategori gizi kurang atau gizi lebih. Hasil bahwa IMT dan kecenderungan ON tidak berhubungan, didukung dengan penemuan pada penelitian lain yang juga tidak menemukan hubungan signifikan antara IMT dan kecenderungan ON. ${ }^{6,14,15,31,32,37}$

Pada penelitian ini, hubungan frekuensi makan, diet khusus, dan alergi dengan kecenderungan $\mathrm{ON}$ adalah tidak signifikan. Hal ini didukung penelitian lain yang mengatakan bahwa alergi tidak memiliki hubungan dengan kecenderungan $\mathrm{ON}^{14}$, kemudian frekuensi atau jumlah makanan yang dikonsumsi juga tidak berhubungan dengan kecenderungan $\mathrm{ON}^{32}$, dan diet khusus seperti vegetarian atau vegan juga tidak berhubungan dengan kejadian ON. ${ }^{31,32,35}$

Beberapa kelemahan pada penelitian ini adalah jawaban responden berpotensi bias atau dapat terjadi salah pemahaman terhadap pertanyaan kuesioner karena beberapa responden, lebih memilih mengerjakan kuesioner di rumah masing-masing. Kemudian, beberapa data yang diperoleh tidak dapat secara nyata menggambarkan kebiasaan atau data responden yang sesungguhnya dan pertanyaan pada kuesioner data demografi kurang dapat menggambarkan data yang sebenarnya. 
Hambatan yang dihadapi selama penelitian, di antaranya beberapa mahasiswa menolak menjadi responden penelitian secara sukarela. Selain itu beberapa responden tidak mengisi jawaban kuesioner secara lengkap. Kemudian, waktu pengambilan data tidak serentak karena jadwal kelas peneliti, asisten penelitian, dan responden tidak sama sehingga membuat responden sulit ditemui untuk proses pengambilan data. Selain itu, waktu yang dibutuhkan untuk melakukan pengambilan data lebih lama dari yang diperkirakan di awal rencana penelitian.

\section{KESIMPULAN DAN SARAN}

Proporsi kecenderungan ON pada mahasiswa prodi kedokteran FK-KMK UGM adalah $44,3 \%$. Ada hubungan yang signifikan antara kegemaran mahasiswa untuk mengakses laman kesehatan dengan kecenderungan $\mathrm{ON}$.

Beberapa saran yang diusulkan adalah peneliti mendorong dilakukannya penelitian lanjutan pada populasi mahasiswa kedokteran dengan sampel yang lebih besar atau pada populasi umum dengan latar belakang yang lebih bervariasi. Penelitian menggunakan instrumen selain ORTO-15 juga dapat dilakukan untuk melihat perbedaan hasil, bila menggunakan ORTO-15 dan tidak, serta penelitian kualitatif yang dapat menggali lebih dalam karakteristik responden yang memiliki tanda dan gejala ON.

\section{UCAPAN TERIMA KASIH}

Penelitian ini mendapat hibah biaya dari prodi ilmu keperawatan FK-KMK UGM. Terima kasih kepada asisten peneliti yang telah membantu dalam proses pengambilan data dan seluruh responden yang terlibat pada penelitian ini.

\section{DAFTAR PUSTAKA}

1. Bratman S. Orthorexia vs. Theories of Healthy Eating. Eat Weight Disord. 2017; 22(3): 381-5.

2. Bartrina JA, Medicina D De, Pública S, Navarra U De. Ortorexia O La Obsesión por La Dieta Saludable. 2007; 57: 313-5.

3. Costa CB, Hardan-Khalil K, Gibbs K. Orthorexia Nervosa: A Review of The Literature. Issues Ment Health Nurs [Internet]. 2017; 38(12): 980-8. Available from: https://doi.org/10.1080/01612840.2017.1371816

4. Hyrnik J, Stochel M, Jelonek I, Siwiec A. Prevalence of Orthorexia Nervosa among Polish Adolescents - Assessment Made by The ORTO-15 The effect of Atipical Antipsychotic Medications in Anorexia Nervosa and Dissociative Disorders in Males : A Case Report. Eur Psychiatry. 2016; 33: S430.

5. Barnes MA, Caltabiano ML. The Interrelationship between Orthorexia Nervosa, Perfectionism, body Image and Attachment Style. Eat Weight Disord. 2017; 22(1): 177-84.

6. Oberle CD, Samaghabadi RO, Hughes EM. Orthorexia Nervosa: Assessment and Correlates with Gender, BMI, and Personality. Appetite [Internet]. 2017; 108: 303-10. Available from: http://dx.doi.org/10.1016/j.appet.2016.10.021

7. Barthels F. Orthorexic Eating Behaviour as a Coping Strategy in Patients with Anorexia Nervosa. Eat Weight Disord - Stud Anorexia, Bulim Obes. 2017; 22(2): 269-76.

8. Gramaglia C, Brytek-Matera A, Rogoza R, Zeppegno P. Orthorexia and Anorexia Nervosa: Two Distinct Phenomena? A Cross-Cultural Comparison of Orthorexic Behaviours in Clinical and NonClinical Samples. BMC Psychiatry. 2017; 17(1): 1-6.

9. Brytek-Matera A, Rogoza R, Gramaglia C, Zeppegno P. Predictors of Orthorexic Behaviours in 
Patients with Eating Disorders: A Preliminary Study. BMC Psychiatry. 2015; 15(1): 1-9.

10. Luck-Sikorski C, Jung F, Schlosser K, Riedel-Heller SG. Is Orthorexic Behavior Common in The General Public? A Large Representative Study in Germany. Eat Weight Disord [Internet]. 2019;24(2):267-73. Available from: http://dx.doi.org/10.1007/s40519-018-0502-5

11. Missbach B, Hinterbuchinger B, Dreiseitl V, Zellhofer S, Kurz C, König J. When Eating Right, is Measured Wrong! A Validation and Critical Examination of The ORTO-15 Questionnaire in German. PLoS One. 2015; 10(8): 1-15.

12. Koven NS, Abry AW. Neuropsychiatric Disease and Treatment Dovepress The Clinical Basis of Orthorexia Nervosa: Emerging Perspectives. 2015; 385-94.

13. Barthels F, Meyer F, Pietrowsky R. Orthorexic and Restrained Eating Behaviour in Vegans, Vegetarians, and Individuals on A Diet. Eat Weight Disord [Internet]. 2018; 23(2): 159-66. Available from: http://dx.doi.org/10.1007/s40519-018-0479-0

14. Reynolds R. Is The Prevalence of Orthorexia Nervosa in An Australian University Population 6.5\%? Eat Weight Disord. 2018; 23(4): 453-8.

15. Varga M, Thege BK, Dukay-Szabó S, Túry F, van Furth EF. When Eating Healthy is Not Healthy: Orthorexia Nervosa and Its Measurement with The ORTO-15 in Hungary. BMC Psychiatry. 2014; 14(1): $1-11$.

16. Dunn TM, Bratman S. On Orthorexia Nervosa: A Review of The Literature and Proposed Diagnostic Criteria. Eat Behav [Internet]. 2016;21:11-7. Available from: http://dx.doi.org/10.1016/j.eatbeh.2015.12.006

17. Ramacciotti CE, Perrone P, Coli E, Burgalassi A, Conversano C. Orthorexia Nervosa in The General Population: A Preliminary Screening Using A Self-Administered Questionnaire (ORTO-15). 2011; 16 (June): 127-30.

18. Saddichha S, Babu GN, Chandra P. Orthorexia nervosa presenting as prodrome of schizophrenia. Schizophr Res [Internet]. 2012; 134 (1): 110. Available from: http://dx.doi.org/10.1016/j.schres.2011.10.017

19. Lopes R, Melo R, Dias B. Orthorexia Nervosa and Comorbid Depression Successfully Treated with Mirtazapine: A Case Report. Eat Weight Disord - Study Anorexia, Bulim Obes. 2018; 0(0): 0.

20. Moroze RM, Dunn TM, Craig Holland J, Yager J, Weintraub P. Microthinking About Micronutrients: A Case of Transition From Obsessions About Healthy Eating to Near-Fatal "Orthorexia Nervosa" and Proposed Diagnostic Criteria. Psychosomatics [Internet]. 2015;56(4):397-403. Available from: http://dx.doi.org/10.1016/j.psym.2014.03.003

21. Park SW, Kim JY, Go GJ, Jeon ES, Pyo HJ, Kwon YJ. Orthorexia Nervosa with Hyponatremia, Subcutaneous Emphysema, Pneumomediastinum, Pneumothorax, and Pancytopenia. Electrolyte Blood Press. 2011; 9(1): 32-7.

22. Fidan T, Ertekin V, Işikay S, Kirpinar I. Prevalence of Orthorexia Among Medical Students in Erzurum, Turkey. Compr Psychiatry. 2010; 51(1): 49-54.

23. Mihailescu A, Diaconescu L, Ciobanu AM, Donisan T. Original Papers The Influence of Emotional Distress on The Academic Performance. 2016; (February 2018).

24. Afolayan JA, State B, Donald B, Onasoga O, A AB, A AJ. Relationship Between Anxiety and Academic Performance of Nursing Students. 2013; 4(5): 25-33.

25. Donini LM, Marsili D, Graziani MP, Imbriale M, Cannella C. Orthorexia Nervosa: Validation of A Diagnosis Questionnaire. Eat Weight Disord. 2005; 10(June): 28-32.

26. Farchakh Y, Hallit S, Soufia M. Association between Orthorexia Nervosa, Eating Attitudes and Anxiety among Medical Students in Lebanese Universities: Results of A Cross-Sectional Study. Eat Weight Disord [Internet]. 2019;24(4):683-91. Available from: https://doi.org/10.1007/s40519-01900724-6.

27. Plichta M, Jezewska-Zychowicz M. Eating Behaviors, Attitudes toward Health and Eating, and Symptoms of Orthorexia Nervosa among Students. Appetite [Internet]. 2019; 137 (September 2018): 114-23. Available from: https://doi.org/10.1016/j.appet.2019.02.022.

28. Gubiec E, Stetkiewicz-Lewandowicz A, Rasmus P, Sobów T. Orthorexia in A Group of Dietetics Students. Med Ogólna i Nauk o Zdrowiu. 2015;21(1):95-100.

29. Bundros J, Clifford D, Silliman K, Neyman Morris M. Prevalence of Orthorexia Nervosa among College Students Based on Bratman's Test and Associated Tendencies. Appetite [Internet]. 2016;101:86-94. Available from: http://dx.doi.org/10.1016/j.appet.2016.02.144.

30. Depa J, Schweizer J, Bekers SK, Hilzendegen C, Stroebele-Benschop N. Prevalence and Predictors of Orthorexia Nervosa among German Students using The 21-Item-DOS. Eat Weight Disord. 2017;22(1):193-9.

31. Herranz Valera J, Acuña Ruiz P, Romero Valdespino B, Visioli F. Prevalence of Orthorexia Nervosa among Ashtanga Yoga Practitioners: A Pilot Study. Eat Weight Disord. 2014;19(4):469-72. 
32. Turner PG, Lefevre CE. Instagram Use is Linked to Increased Symptoms of Orthorexia Nervosa. Eat Weight Disord. 2017;22(2):277-84.

33. Bağci Bosi AT, Çamur D, Güler Ç. Prevalence of Orthorexia Nervosa in Resident Medical Doctors in The Faculty of Medicine (Ankara, Turkey). Appetite. 2007; 49(3): 661-6.

34. McComb SE, Mills JS. Orthorexia nervosa: A Review of Psychosocial Risk Factors. Appetite [Internet]. 2019; 140 (October 2018): 50-75. Available from: https://doi.org/10.1016/j.appet.2019.05.005.

35. Dunn TM, Gibbs J, Whitney N, Starosta A. Prevalence of Orthorexia Nervosa is Less than $1 \%$ : Data from A US Sample. Eat Weight Disord. 2017;22(1):185-92.

36. Almeida C, Vieira Borba V, Santos L. Orthorexia Nervosa in A Sample of Portuguese Fitness Participants. Eat Weight Disord [Internet]. 2018; 23(4): 443-51. Available from: http://dx.doi.org/10.1007/s40519-018-0517-y

37. Karakuş B. Orthorexia Nervosa Trends among Students of Nutrition and Dietetics Department at A University in Istanbul. North Clin Istanbul. 2017; 4(2): 117-23. 